Jurnal Populika

Volume 8, Nomer 1, Januari 2020

\title{
MELIHAT KONSTRUKSI GENDER DALAM PROSES MODERNISASI DI YOGYAKARTA
}

\author{
Dwi Astuti \\ astibudiyanto@gmail.com
}

\section{Program Studi Sosiologi Fakultas Ilmu Sosial dan Ilmu Politik Universitas Widya Mataram}

\begin{abstract}
Abstrak
Like we know gender construction is always connected to cultural, and when the culture change it will effect gender construction. Yogyakarta lika other country in Indonesia,have high experience in modernisasi. This process will effect to culture in small or big part. This paper is a discription and explanation about gender construction in Yogyakarta on this era, written based on research. This research was conducted by necessity to know about the changes gender construction in community that have modernisation process. This process can create new relation between man and woman in many aspect. As a city that have strong patriarkhie culture, Yogyakarta can not avoid the modernisation process. And this process can influence that patriakhie culture, and than influence gender ralation indirectly in Yogyakarta. Gender construction in this paper is seen from four aspects, those are education, economi, politic dan double garden. Modernisation give effects on same aspek of gender construction. Although same aspect specially in public domain there is same changes in gender construction like in education, economi dan politic, but in domestic area specially doble garden, we can see that we find remains thd same. So we still can see the gender bias in domestic area. This research doing with discriptif method.
\end{abstract}

Keyword : modernisation, gender construction

\section{PENDAHULUAN.}

Berbicara tentang gender hampir tidak pernah ada habisnya. Meskipun persoalan ini sudah lama menjadi perhatian baik oleh masyarakat maupun oleh pembuat kebijakan, namun permasalahan gender masih banyak ditemukan dalam masyarakat. Beberapa persoalan yang biasa ditemukan di masyarakat antara lain, pertama, masyarakat masih sering salah dalam memahami apa itu gender dan apa itu jenis kelamin. Kedua, terjadinya bias gender dan yang ketiga adalah terjadinya ketidakadilan gender.

Berkaitan dengan permasalahan pertama. Masyarakat masih banyak yang tidak bisa membedakan apa itu gender dan apa itu jenis kelamin. Masyarakat masih menganggap bahwa keduanya adalah sama. Padahal keduanya adalah konsep yang sangat berbeda. Jika jenis kelamin berbicara tentang penggolongan/pengelompokan dua manusia berdasarkan ciri-ciri biologis yang dibawa sejak lahir, maka gender adalah pengelompokkan/pembagian manusia berdasarkan peran sosial.

Persoalan kedua adalah bias gender dalam masyarakat. Bias gender yang terjadi sebenarnya bersumber juga dari kurang pahamnya masyarakat tentang perbedaan jenis kelamin dan gender. Bias gender adalah kondisi dimana masyarakat menganggap persoalan gender dianggap sebagai persoalan jenis kelamin. Contohnya masih ada perdebatan apakah perempuan boleh bekerja di luar rumah atau harus mengurusi rumah tangga? Perdebatan ini muncul karena ada anggapan di masyarakat bahwa perempuan mengerjakan pekerjaan rumah tangga dan laki-laki bekerja di kantor 
adalah takdir. Padahal pembagian pekerjaan seperti itu bukanlah takdir tetapi peran sosial yang dibentuk. Kesulitan untuk membedakan apakah ini persoalan takdir atau persoalan peran sosial yang dibentuk inilah yang dikenal dengan bias gender. Bias gender ini juga bersumber dari ketidakpahaman masyarakat membedakan jenis kelamin dan gender.

Persoalan ketiga adalah ketidakadilan gender. Pemahaman masyarakat yang kurang tepat tentang dua hal sebelumnya, melahirkan anggapan-anggapan yang juga bisa disebut secara sederhana dengan istilah konstruksi. Ada banyak anggapan-anggapan yang memunculkan ketidakadilan perlakuan terhadap laki-laki dan perempuan. Ketidakadilan tersebut antara lain adanya hambatan bagi perempuan untuk bekerja di ranah publik. Contoh lain dari ketidakadilan karena anggapan yang bias adalah perempuan tidak perlu menempuh pendidikan tinggi, karena hanya akan menjadi ibu rumah tangga.

Tiga persoalan di atas adalah persoalan-persoalan yang masih banyak muncul di masyarakat. Namun persoalan-persoalan di atas memang tidaklah selalu sama. Seperti sudah dipaparkan di atas, gender adalah persoalan peran sosial bukan persoalan takdir. Karena berkaitan dengan peran sosial maka bukan harga mati dan bisa berubah sesuai dengan konteks masyarakat. Seperti apa masyarakat menempatkan atau mengatur peran sosial antara laki-laki dan perempuan, bisa berbeda-beda antara satu tempat dengan tempat lain. Dan bisa berbeda antara satu waktu dengan waktu yang lain. Contohnya kesempatan perempuan untuk menempuh pendidikan. Masyarakat pasti tidak akan pernah lupa dengan R.A Kartini. Seorang perempuan dari Jepara yang telah mampu merubah anggapan tentang pendidikan bagi perempuan. Pada masanya perempuan dilarang untuk bersekolah. Sekolah hanya untuk laki-laki. Namun sebagai seorang perempuan hati nuraninya berontak dengan kondisi tersebut, dan mendirikan sekolah untuk perempuan. Melawan anggapan yang ada dengan memberikan kesempatan kepada perempuan-perempuan untuk bersekolah. Dan kita bisa lihat sekarang bagaimana peran sosial tentang pendidikan ini berubah. Sudah merupakan hal yang biasa bagi masyarakat ketika melihat perempuan bersekolah. Bahkan saat ini banyak perempuan yang mampu menempuh pendidikan sampai jenjang pendidikan tinggi. Ini bukti bahwa gender berbicara tentang peran sosial yang bisa berubah dan bukan takdir.

Namun sekali lagi perlu kita perhatikan bahwa belum semua persoalan gender ini selesai. Beberapa masalah masih ada seperti disampaikan diawal tulisan ini. Seperti apa sesungguhnya gambaran permasalahan gender ini dalam masyarakat khususnya dalam perkembangan dari waktu ke waktu. Peran sosial gender bergantung kepada konteks masyarakatnya, sehingga ketika masyarakat berubah maka peran sosial juga akan berubah. Anggapan dalam masyarakat tentang gender juga berubah. Secara khusus tulisan ini akan membahas tentang perubahan konstruksi gender, atau anggapan tentang gender dalam masyarakat dalam rposes modernisasi. Kaitan antara perubahan konstruksi gender dengan modernisaasi dianggap menarik karena modernisasi membawa atau menawarkan nilainilai baru ditengah-tengah masyarakat, yang bisa berpengaruh dalam merubah anggapan masyarakat tentang gender. Salah satunya adalah nilai rasionalitas yang dibawa oleh proses modernisasi, dimana bisa berdampak pada cara masyarakat dalam membagi peran sosial antara laki-laki dan perempuan.

Tulisan ini didukung oleh beberapa fakta berdasarkan hasil penelitian. Penelitian ini dilakukan di wilayah kota Yogyakarta dan sekitarnya. Pemilihan kota Yogyakarta sebagai lokasi penelitian menarik karena Yogyakarta dikenal sebagai kota budaya, dimana masih melakukan pelestarian terhadap tradisi-tradisi lama. Keberadaan tradisi selama ini ditengarai menjadi penguat terbentuknya konstruksi gender. Modernisasi yang menawarkan nilainilai baru menggantikan tradisi, akan berpengaruh pada konstruksi gender yang ada.Tarik menarik antara fenomena modernisasi dengan pelestarian tradisi lama, menjadi konteks yang menarik bagi perekembangan konstruksi gender di masyarakatnya.

\section{METODE PENELITIAN.}

Mengacu pada tujuan dan topik yang diangkat dalam penelitian ini metode yang 
sesuai yang digunakan adalah metode diskriptif. Metode diskriptif adalah metode dalam meneliti status sekelompok manusia, suatu obyek, suatu set kondisi, suatu sistem pemikiran atau suatu peristiwa di masa sekarang. Tujuan dari penelitian diskriptif ini adalah untuk membuat dekripsi/ gambaran seacra sistematis faktual dan akurat mengenai fakta-fakta dan sifat-sifat serta hubungan antar fenomena (Moh. Nasir , 1988)

Menurut Whitney metode diskriptif adalah pencarian fakta dengan interpretasi yang tepat. Mempelajari masalah-masalah dalam masyarakat serta situasi-situasi tertentu. Dalam metode diskriptif peneliti bisa saja membandingkan antar fenomena tertentu sehingga merupakan komparasi. Adakalanya melakukan klasifikasi, serta penelitian terhadap fenomena dengan menetapkan suatu standart tertentu, oleh beberapa ahli mtematika disebut survei normatif.

Ciri dari metode diskriptif adalah membuat gambaran mengenai situasi atau kejadian sehingga metode ini berkehendak mengadakan akumulasi data dasar belaka.

Menggunakan istilah tokoh lain yaitu Denzin dan Lincoln, penelitian kualitatif dengan multi-metodologi. Dikatakan penelitian kualitatif sebagai perangkat interpretatif terhadap fenomen sosial. Penelitian kualitatif ini tidak memiliki teori atau paradigmanya yang tersendiri. Model penelitian kualitatif digunakan dalam banyak disiplin secara terpisah, pendekatannya tidak memiliki seperangkat metode tertentu yang sepenuhnya menjadi miliknya. Penelitian kualitatif bisa menggunakan semiotik, narasi, isi, diskursus, arsip bahkan menggunakan data statistik dalam menginterpretasikan fenomena. (Agus Salim, 2001)

\section{LANDASAN TEORI}

\section{a. Konstruksi Gender.}

Mengacu pada Kamus Besar Bahasa Indonesia, kata kontsruksi berarti bangunan atau model atau tatanan. Dalam Kamus Besar bahasa Indonesia kata konstruksi memang banyak digunakan dalam bidang arsitektur. Namun konstruksi yang dimaksud dalam tulisan ini adalah konstruksi sosial. Sebuah tatanan atau cara berpikir atau model bepikir terhadap suatu masaalah.

Salah satu tokoh yang berbicara tentang konstruksi sosial berkaitan dengan masalah gender adalah Mansour Fakih. Dalam bukunya ia meyebut tentang konstruksi gender. Istilah konstruksi gender muncul digunakan untuk menjelaskan bias gender dan ketidakadilan gender yang terjadi di masyarakat. Dijelaskan bahwa bias gender dan ketidakadilan gender yang terjadi saat ini adalah dibentuk, diajarkan, disosialisasikan secara berulang-ulang sampai menjadi konstruksi gender.

Dalam bukunya yang berjudul "Analisis Gender dan Transformasi Sosial" Mansour Fakih menyebutkan sejarah perbedaan gender antara laki-laki dan perempuan terjadi melewati proses yang sangat panjang. Terbentuknya perbedaan gender dikarenakan banyak hal diantaranya di bentuk, disosialisasikan, terus diperkuat bahkan dikonstruksikan. (Mansour Fakih, 1987).

Karena proses sosialisasi dan rekonstruksi berlangsung secara mapan dan akhirnya mennjadi sulit dibedakan apakah yang tejadi itu persoalan jenis kelamin yang besifat takdir ataukah persoalan gender yang merupakan bentukan.

Ada dua pembedaan manusia yaitu laki-laki dan perempuan yang melahirkan dua macam konsep yaitu kata gender dan kata seks (jenis kelamin). Kata seks atau jenis kelamin adalah pembagian dua jenis kelamin manusia yang ditentukan secara biologis. Misalnya lakilaki memiliki penis, memiliki jakala, memproduksi sperma. Sedangkan perempuan memproduksi sel telur, memiliki alat reproduksi rahim, memiliki vagina, dan mempuyai alat menyusui. Alat-alat biologis tersebut tidak dapat dipertukarkan, tidak berubah dan merupakan kodrat (ketentuanTuhan). Sedangkan konsep gender yaitu sifat yang melekat pada manusia, laki-laki dan perempuan yang dikonstruksi ecara sosial maupun kultural. Misalnya, laki-laki itu kuat, rasional, jantan, perkasa dll. Sementara perempuan lembut, cantik, emosional, keibuan. Ciri dari sifat laki-laki dan perempuan itu sendiri bisa dipertukarkan, bisa diubah atau berubah 
dari waktu ke waktu, dan bisa berbeda dari satu budaya atau tempat dengan kebudaya atau tempat yang lain. (Mansour Fakih :1999).

Sementara itu penulis lain, Julia Cleves, mendefinisikan gender sebagai seperangkat peran yang bisa menyampaikan pesan apakah kita feminin atau maskulin. Perangkat perilaku khusus ini, yang mencakup cara pakaian, sikap, kepribadian, bekerja di dalam dan di luar rumah, seksualitas, dan tanggung jawab keluarga. Setiap masyarakat menggunakan penggambaran yang berbeda-beda terhadap adanya perbedaan gender ini. (Julia Cleves : 2007).

Jude Browne mengatakan "sex is deemed category od analysis wich relates to the identification of an individual by biological endowments and functions. Sex inviked an analysis of men and womwn based upon an a priori set of assumtions about how each sex behave". Dan "Gender is use to classify humans and to explain their behaviour in predominantly social rather than biological form. Gender concern with the ascription of social vharacteristics such as womanly, manly, feminine and maskulin all of wich can be seen as culturall variable and not necessarelt associated with the sex of individual". (Jude Brown. 20017).

Terjadinya kesalahpahaman dan bias tentang gender dalam masyarakat tersebut akhirnya berpotensi menimbulkan ketidakadilanketidakadilan yang terjadi pada perempuan. Beberapa bentuk ketidakadilan tersebut antara lain :

- Gender dan marginalisasi dalam arti sesungguhnya marginalisasi adalah kata yang digunakan untuk menggambarkan suatu fakta apakah sesuatu benda di dalam atau diluar suatu kelompok sosial. Dalam analisa tentang ketidakadilan gender, marginalisasi memiliki arti bahwa perempuan tidak menjadi bagian dari proses maupun hasil pembangunan. Contohnya ,revolusi hijau.

- Gender dan subordinasi, yaitu sikap yang menempatkan perempuan pada posisi yang tidak penting. Anggapan bahwa perempuan itu irasional, emosional, tidak bisa memimpin tetapi hanya pantas mengerjakan pekerjaan rumah, membuat masyarakat menganggap perempuan posisinya kurang penting.

- Gender dan stereotype, adalah pelabelan atau penandaan masyarakat terhadap suatu kelompok tertentu. Namun selama ini stereotype kebanyakan adalah lebel yang cenderung negatif. Contohnya, penandaan yang berawal dari asumsi bahwa perempuan suka bersolek dalam usaha memancing lawan jenis, sehingga jika terjadi pelecehan seksual justru perempuan yang disalahkan.

- Gender dan kekerasan, adalah serangan atau invasi terhadap fisik maupaun intregitas mental psikologis seseorang. Kekerasan terhadap perempuan berasal daria nggapan gender (gender-related violence). Kekerasan ini terjadi karena ketidaksetaraan kekuatan dalam masyarakat. Contohnya :Perkosaan, pemukulan, pelacuran, pornogafi, dan lain sebagainya.

- Gender dan beban kerja, adanya anggapan perempuan memiliki sifat "alami" untu merawat, memelihara, melindungi, mendidik dan sebagainya menciptakan anggapan bahwa perempuanlah yang pantas memegang tanggungjawab melakukan pekerjaan rumahtangga. Bagi kelas menengah dan golongan berpendidikan, ada kesempatan untuk bekerja di ranah publik. Namun karena anggapan bahwa pekerjaan rumah tangga adalah pekerjaan perempuan, beban kerja rumah tangga tersebut tetap berada dipundak perempuan. Sehingga perempuan justru memiliki beban kerja ganda.

Dari pembedaan ini jelas terlihat bahwa gender merupakan anggapan atau konstruksi yang dibuat oleh manusia atau masyarakat. Anggapan ini terus dikonstruksikan dalam waktu lama dan dari generasi ke generasi. Sehingga bisa dipahami jika dalam waktu yang lama ketidakadilan gender menjadi hegemoni. Yaitu membenarkan penguasaan suatu kelompok atas kelompok lain, bahkan tidak disadari oleh kelompok yang dikuasai. Diperlukan pemikiran kritis untuk bisa memutus rantai ini.

\section{b. Modernisasi.}


Modernisasi secara sederhana memiliki arti proses menjadi modern. Sehingga modernisasi terjadi ketika sebuah masyarakat bergeser atau berproses menjadi masyarakat modern. Kata "modern" berasal dari bahasa latin "modernus" yang artinya "sekarang" atau "saat ini". menjadi modern berarti menjadi up-to-date. Modern juga di analogikan dengan berbagai hal seperti barang, gaya, seni, cara berperilaku dan cara berpikir. (John Scott, 2012).

Dalam tulisannya Teori Sosial, Masalah-Masalah Pokok Dalam Sosiologi, John Scott juga mengaitkan proses menjadi modern ini sebagai proses pergeseran dari pengetahuan klasik dengan perubahan munculnya ilmu pengetahuan yang lebih rasional, yang dikenal dengan istilah "renaisans".

Selanjutnya disebutkan bahwa sebuah masyarakat dianggap modern ketika masyarakat telah memisahkan diri dari kebodohan dan tradisi. Kondisi sosial modern adalah sebuah cara hidup yang diorganisasikan secara rasional, ia adalah kondisi kemapanan pengetahuan dasar yang rasional dan penilaian yang kritis.

Sementara modernisasi adalah proses dimana suatu masyarakat berubah menjadi semakin modern, sesuai dengan pengertian diatas. Semakin rasional.

Salah satu tokoh yang membahas secara lengkap tentang modernisasi adalah Max Weber. Weber melihat modernisasi sebagai sebuah proses pertumbuhan rasionalitas praktis dalam seluruh aspek kehidupan sosial. Dan gejala ini menyebar dari masyarakat Eropa dan menjalar ke belahan dunia lain. Contoh tindakan rasional salah satunya adalah tindakan ekonomi. (John Scott, 2012).

Transisi dari masyarakat tradisional menuju masyarakat modern dapat dipahami sebagai proses rasionalisasi. Sifat pergeseran ini secara detail digambarkan oleh Talcot Person dengan variabel pola. Dimana pergeseran dari masyarakat tradisional menuju masyarkat modern ini bisa dilihat dari empat variabel :

1. Askripsi menjadi Prestasi.

Hal ini berkaitan dengan penilaian terhadap kategori tertentu. Jika sebelumnya penilaian didasarkan pada siapa personalnya maka dalam pergeseran menuju modern penilian didasarkan pada pertimbangan apa yang bisa dia lakukan. Sehingga pertimbangan terhadap penilaian semakin rasional.

2. Afektivitas menjadi Netralitas.

Ini merupakan perubahan sosial pada aspek hubungan sosial. Jika sebelumnya hubungan sosial lebih bersifat emosional maka dalam pergeseran menjadi modern hubungan sosial ini lebih didasarkan pada pertimbangan pragmatis.

3. Difusitas menjadi Spesifikitas.

Variabel ini berkiatan dengan tujuan atau kepentingan. Pada masyarakat tradisional ada ketidakjelasan tujuan atau kepentingan sementara dalam masyarakat yang bergeser modern maka kepentingan dan tujuan sangat jelas dan bersifat spesifik.

4. Pertikularisme menjadi Universalisme.

Partikularisme dan universalisme berkaitan dengan peran orang-orang dalam masyarakat. Jika dalam partikularisme peran orang sangat berbeda-beda antara satu dengan yang lain atau unik, maka dalam masyarakat modern peran orang semakin universal mengarah kepad tujuan bersama atau tujuan yang lebih besar. Peran seseorang lebih untuk mendukung tujuan universal.(John Scott, 2012)

Spirit rasionalitas kemudian disebarkan melalu perkembangan ilmu pengetahuan, politik, dunia ekonomi yang memungkinkan dilakukannya resionalisasi kehidupan sosial secara komprehensif pada semua bidang kehidupan. Termasuk di dalamnya adalah budaya atau tradisi. Rentang tindakan yang tunduk kepada yang non-rasional semakin sedikit dan semakin mengecil dan hanya terbatas pada lingkup keluarga, kekerabatan dan tempattempat yang sifatnya pribadi. (John Scott, 2012).

Tokoh lain Anthony Giddens menjelaskan modernisasi sebagai proses pergeseran dari masyarakat berbasis pertanian (agraris) menuju masyarakat berbasis industri. Bahkan jika kegiatan pertanian masih dilakukan, tujuannya bukan untuk memenuhi kebutuhan sendiri tetapi untuk memenuhi kebutuhan pasar.

Giddens juga berpendapat modernisasi sebagai sebuah proses penghancuran atas tradisi alami dengan tujuan untuk menyatukan konstruksi dari sebuah gagasan.(Giddens, 1981) 
Ahli lain Tourine menjelaskan modernisasi sebagai hal yang berbeda dengan pembangunan. Modernisasi bukan pembangunan yang hanya bercerita tentang ekonomi dan pertumbuhannya, melainkan merupakan elemen idiologi, elemen sosiologi, elemen politik dan elemen kultural yang terjadi secara kolektif dan mengglobal (Tourine:1992).

\section{PEMBAHASAN.}

Yogyakarta merupakan wilayah yang juga mengalami proses modernisasi. Ada banyak contoh proses rasionalisasi dalam banyak aspek kehidupan. Contohnya dari aspek ekonomi yang semakin didasarkan kepada cara berpikir yang semakin rasional. Hubungan sosial juga semakin pragmatis bukan lagi emosional. Yang kelihatan lagi adalah dalam bidang birokrasi dimana birokrasi dijalankan dengan cara yang semakin rasional. Begitu juga dengan aspek seni, gaya hidup, dan budaya yang semakin "kekinian". Tidak hanya "kekinian" namun juga semakin sama dengan wilayah-wilayah lain. Tidak ada keunikan namun mendukung pada nilai yang universal.

Bagaimana pergeseran ke arah modern ini kemudian memberikan dampak kepada cara berpikir yang baru tentang relasi gender? Apakah terjadi perubahan konstruksi gender dengan perubahan tersebut?

Dengan fakta-fakta yang berupa persepsi yang diperoleh melalui penelitian kita akan melihat ada atau tidaknya pergeseran tersebut. Dan akan kita lihat konstruksi gender sepeti apa yang ada dalam masyarakat Yogyakrta saat ini?

Untuk menjawab persoalan ini kita akan melihat dari beberapa aspek yang mewakili konstruksi gender dan menurut definisi modernisasi akan terpengaruh dan mengalami pergeseran. Aspek-aspek yang akan dipakai untuk melihat konstruksi gender tersebut adalah : aspek pendidikan, aspek politik, aspek ekonomi dan aspek beban ganda.

\section{a. Aspek Pendidikan}

Indikator pertama berkaitan dengan anggapan di masyarakat, ada atau tidaknya hambatan bagi perempuan untuk menempuh pendidikan dan pelatihan tertentu. Hal ini penting dilihat karena selama ini masyarakat beranggapan perempuan tidak terlalu membutuhkan pendidikan karena nantinya hanya akan menjadi pendamping laki-laki.

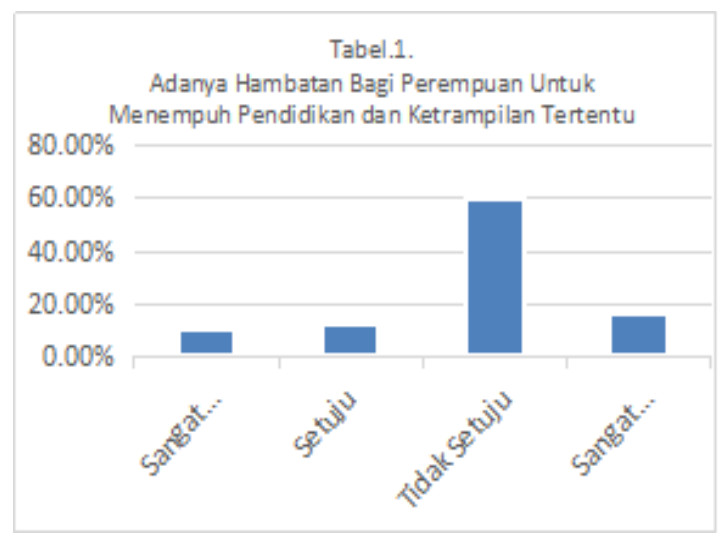

Dari hasil penelitian ini dapat dilihat bahwa hampir sebagian besar masyarakat tidak merasakan hambatan terhadap pendidikan dan pelatihan bagi kaum perempuan. Hampir $60 \%$ menyatakan tidak setuju dengan pernyataan tersebut. Namun perlu kita catat dan perhatikan bahwa masih ada kurang lebih $15 \%$ yang menyatakan setuju atau sangat setuju. Artinya dalam kenyataan masih ditemukan hambatan untuk menempuh pendidikan dan pelatihan bagi perempuan.

Indikator berikutnya berkaitan dengan perlakuan yang berbeda antara laki-laki dan perempuan berkaitan dengan pencapaian tingkat pendidikan. Selama ini masyarakat menganggap bahwa laki-laki lah nantinya akan menjadi pencari nafkah utama bagi keluarganya, sehingga harus dibekali dengan pendidikan yang cukup. Sementara perempuan dianggap sebagai pencari nafkah nomor dua, sehingga dianggap tidak terlalu penting untuk menempuh pendidikan tinggi. 


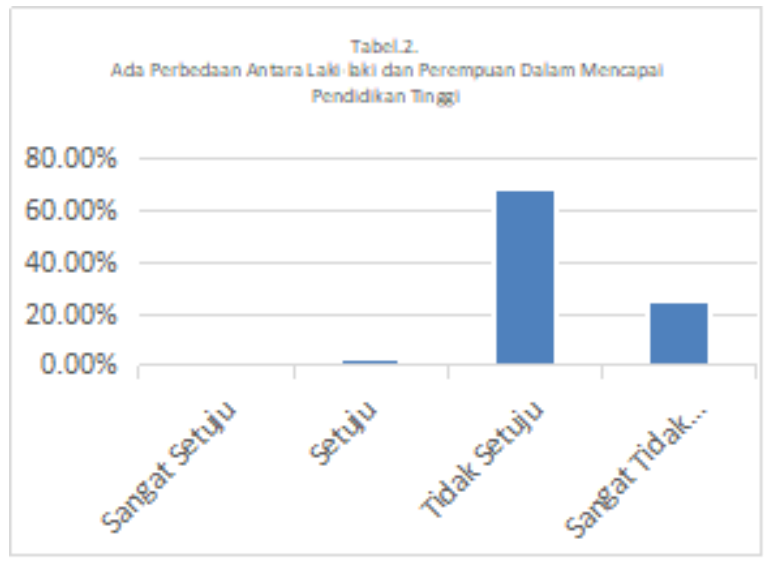

Dari hasil penelitian menunjukkan bahwa $(68,8 \%)$ responden menjawab tidak setuju, $(25,3 \%)$ tidak setuju, $(3,3 \%)$ setuju dan $(2,3 \%)$ sangat setuju. Hampir sama dengan kesempatan untuk menempuh pendidikan dan ketrampilan bagi perempuan, sudah tidak ada lagi pembedaan antara laki-laki dan perempuan dalam menempuh pendidikan tinggi. Namun demikian masih juga ditemukan jawaban yang mendukung anggapan yang sebaliknya. Yaitu masih ada yang menganggap adanya pembedaan itu.

Indikator berikutnya, adalah apakah ada perlakuan yang berbeda anatara laki-laki dan perempuan dalam mendapatkan penghargaan atau prestasi dalam pendidikan. Diskriminasi gender sebagai hasil dari konstruksi, tidak hanya terjadi dalam proses pengambilan keputusan untuk menempuh pendidikan tetapi juga bisa terjadi ketika sudah menempuh pendidikan. Hal ini salah satunya bisa dilihat dari bagaimana penghargaan yang diberikan kepada laki-laki dan perempuan saat menempuh pendidikan.

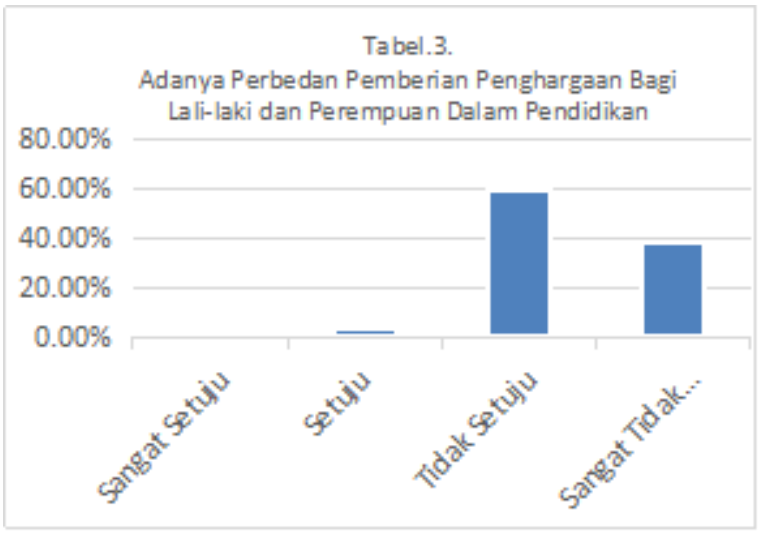

Penelitian menunjukkan bahwa (59,8\%) menyatakan tidak setuju, $(38,2 \%)$ menyatakan sangat tidak setuju, $(3,3 \%)$ menyatakan setuju dan $(0,1 \%)$ menyatakan sangat setuju. Dari jawaban ini bisa dilihat bahwa sebagian masyarakat menyatakan tidak ada diskriminasi dalam pemberian penghargaan dalam pendidikan antara laki-laki dan perempuan.

\section{b. Aspek Ekonomi}

Untuk relasi gender dalam aspek ekonomi, diukur antara lain dari beberapa hal yaitu ada tidaknya hambatan bagi perempuan untuk bekerja, ada tidaknya perlakuan yang berbeda dalam pekerjaan antara laki-laki dan perempuan, upah perempuan yang hanya dianggap sebagai tambahan dan perempuan lebih rawan pelecehan dalam lingkungan kerja.

Apakah ada hambatan bagi perempuan untuk bekerja/ mencari nafkah? Persoalan ini berkaitan dengan konstruksi peran domestik perempuan. Konstruksi yang terbentuk dimana masyarakat menganggap bahwa tanggung jawab perempuan adalah pekerjaan rumah tangga. Sehingga ketika perempuan memutuskan untuk bekerja, sering mendapat hambatan berkaitan dengan peran domsetik ini. Hambatan bisa datang dari maupun dari keluarga besar. Berkaitan dengan aspek ini, dari hasil penelitian menunjukkan, 


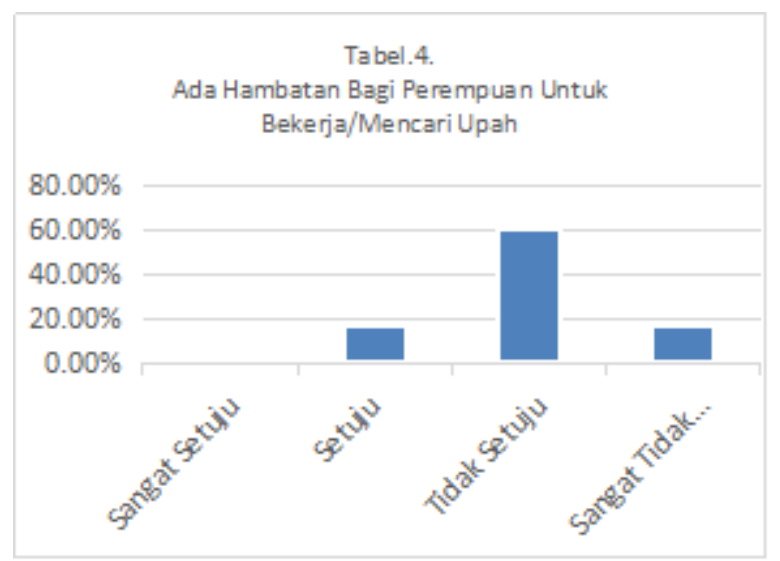

$(61,2 \%)$ menyatakan tidak setuju, $(16,2 \%)$ menyatakan sangat tidak setuju, $(16,2 \%)$ menyatakan setuju dan $(1,43 \%)$ menyatakan sangat setuju. Memang presentase terbesar jawaban adalah tidak setuju, namun dalam presentase yang cukup banyak juga yaitu 16,2\% menyatakan setuju. Artinya masih cukup banyak perempuan yang mengalami hambatan ketika memutuskan untuk bekerja/mencari nafkah. Artinya anggapan perempuan adalah bekerja di rumah tangga masih ada.

Indikator berikutnya berkaitan dengan perempuan setelah bekerja Apakah ada hambatan bagi peningkatan karir perempuan di tempat kerja dibandingkan dengan laki-laki? Aspek ini dilihat dari posisi ketika perempuan sudah masuk ke dunia publik/bekerja. Konstruksi gender terkadang menyebabkan perempuan memiliki pertimbangan lebih banyak untuk meniti karir yang lebih tinggi, karena akan menuntut tanggung jawab lebih, dan artinya akan mengganggu tugas domestiknya. Hambatan ini bisa muncul dari suami, tetapi bisa juga dari perempuan itu sendiri, karena konsrruksi peran domestik ini tidak hanya terjadi pada laki-laki tetapi juga pada perempuan itu sendiri. Dalam aspek ini, hasil penelitian menunjukkan

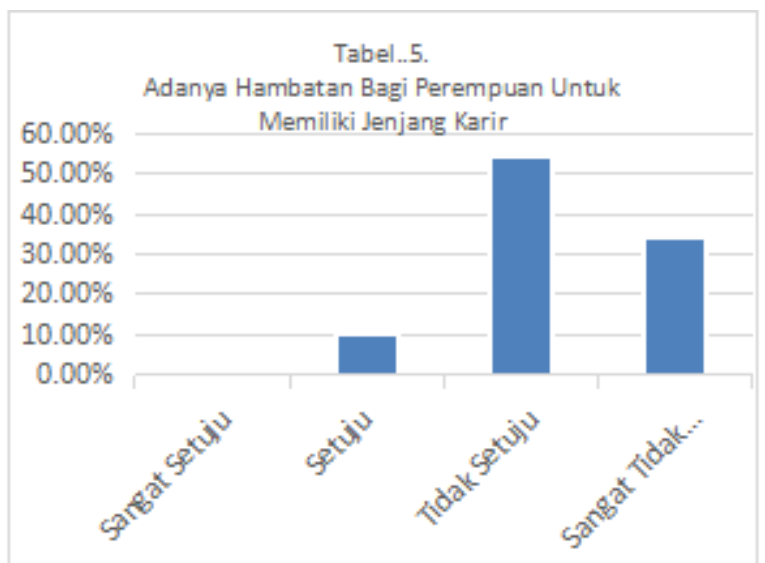

(54,5\%) menyatakan tidak setuju, $(34,4 \%)$ menyatakan sangat tidak setuju, (10,5\%) menyatakan setuju dan $(0,47 \%)$ menyatakan sangat tidak setuju. Dengan demikian sebagian besar sudah tidak mengalami hambatan karir dalam lingkungan kerjanya. Namun masih ada $10,5 \%$ yang menyatakan adanya hambatan karir, karena kontruksi domestifikasi ini.

Persoalan lain yang dihadapi oleh perempuan ditempat kerja adalah apakah lakilaki dan perempuan diberikan hak yang sama ditempat kerja. Terutama berkaitan dengan upah atau imbalan. Aspek ini berkaitan dengan konstruksi gender dalam masyarakat yang menganggap bahwa perempuan adalah pencari nafkah tambahan atau pencari nafkah nomor dua. Sementara laki-laki adalah pencari nafkah utama. Bekaitan dengan aspek ini, hasil penelitian menunjukkan sebagai berikut,

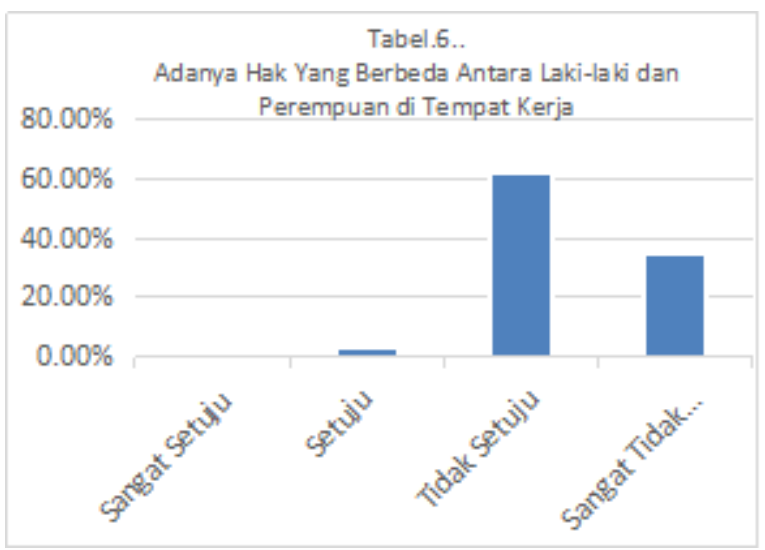

$(62,2 \%)$ orang menyatakan tidak setuju, $(35 \%)$ menyatakan sangat tidak setuju, $(2,9 \%)$ menyatakan setuju dan $(0 \%)$ menyatakan sangat 
tidak setuju. Disini terlihat bahwa hampir semua menyatakan tidak setuju, dengan pernyataan bahwa ada perbedaan upah antara laki-laki dan perempuan di tempat kerja. Kondisi ini sedikit banyak berkaitan dengan regulasi yang mengatur tentang upah, yang memberikan hak yang sama baik untuk laki-laki maupun perempuan.

Ketidakadilan gender yang lain dalam aspek ekonomi adalah, persoalan akses terhadap aset ekonomi. Laki-laki bisanya memiliki akses terhadap aset ekonomi lebih besar dibandingkan dengan perempuan. Misalnya, kredita, tanah, kendaraan, dan sebagainya. Apakah ada pembedaan antara laki-laki dan perempuan dalam hal penguasaan aset ekonomi? Tanggapan informan terhadap penyataan tersebut, berdasarkan hasil penelitian adalah,

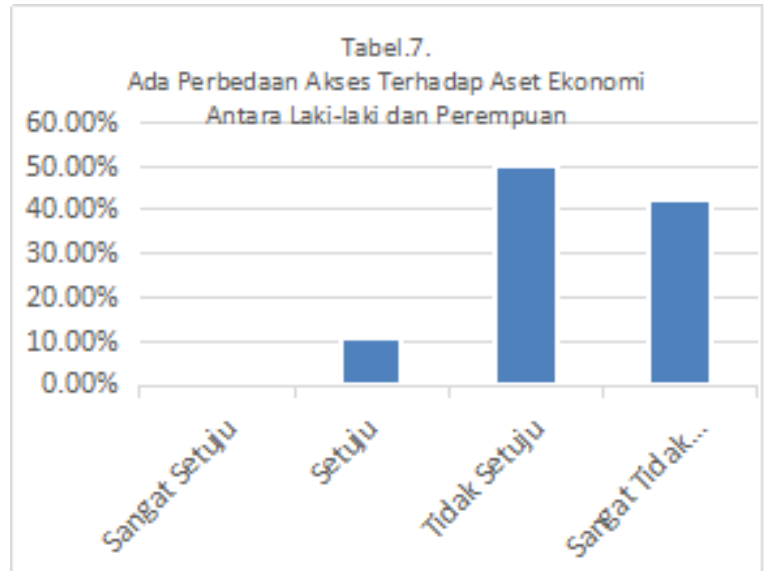

$(50,2 \%)$ menyatakan tidak setuju, $(42,6 \%)$ menyatakan sangat tidak setuju, (11\%) menyatakan setuju dan $(0,95 \%)$ menyatakan sangat setuju. Tidak ada lagi anggapan yang membeda-bedakan laki-laki dan perempuan dalam hal akses ekonomi. Masih ada $11 \%$ yang menyatakan adanya pembedaan, namun sebagian besar menyatakan sikap tidak setuju dengan pernyataan.

Hal lain yang berkaitan dengan persoalan ekonomi adalah adanya anggapan dalam masyarakat yaitu bahwa pendapatan perempuan adalah pendapatan nomor dua/tambahan dibandingkan dengan pendapaan laki-laki. Berkaitan dengan pernyataan ini, jawaban dari hasil penelitian adalah sebagai berikut,

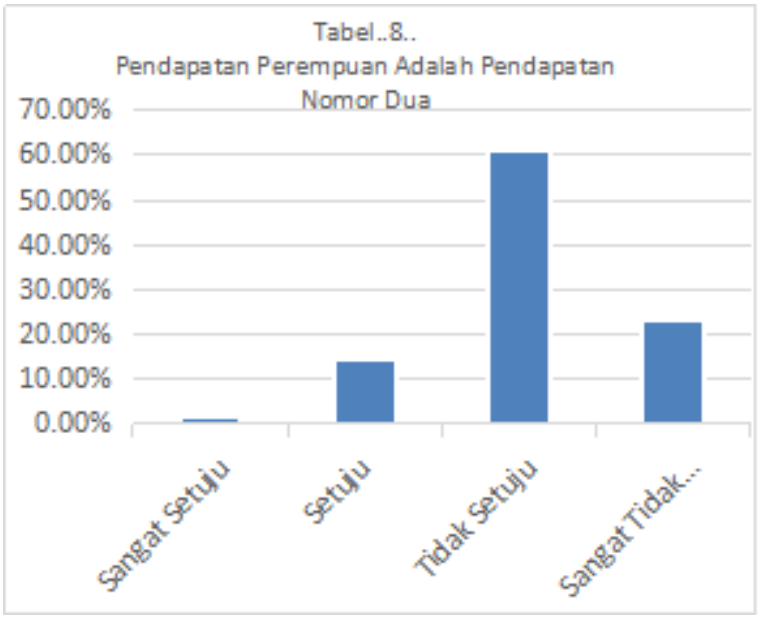

$(60,8 \%)$ menyatakan tidak setuju, $(23, \%)$ menyatakan sangat tidak setuju, (14,3\%) menyatakan setuju dan $(1,9 \%)$ menyatakan sangat tidak setuju. Jadi hampir sebagian besar menyatakan bahwa tidak ada anggapan bahwa pendapatan perempuan adalah pendapatan nomer dua. Ada 14,3\% menyatakan setuju bahwa pendapatan perempuan adalah pendapatan nomor dua.

\section{c. Aspek Politik}

Dari sisi regulasi, ruang demokrasi bagi perempuan di Indonesia semakin besar. Bahkan ada persyaratan terettnu yang mengharuskan partai politik melibatkan perempuan. Namun dalam kenyataannya terlibatnya perempuan dalam dunia politik merupakan perjuangan yang berat. Hal ini karena konstruksi budaya patriarki dan konstruksi agama. Yang beranggapan tidak layak masyarakat dipimpin oleh seorang perempuan. (DiahY Suradiredja \&Syafrizaldy Jpang, 2014). Dunia politik adalah dunia yang keras, dan anggapan masyarakat dunia politik ini tidak pantas untuk perempuan yang memiliki karakter kurang bisa mengambil keputusan dan menanggung resiko. (Mansour Fakih, 2007). Untuk melihat aspek politik ini, penelitian ini mengukur dari beberapa indikator antara lain: kepantasan perempuan untuk berkarir dibidang politik, persolan kepemimpinan dan adanya syara tjenis kelamin tertentu untuk jabatan tertentu.

Untuk pertanyaan pertama dalam aspek politik, berkaitan dengan ada atau tidaknya hambatan bagi perempuan untuk masuk dalam 
dunia politik. Dan jawaban terhadap pernyataan ini adalah,

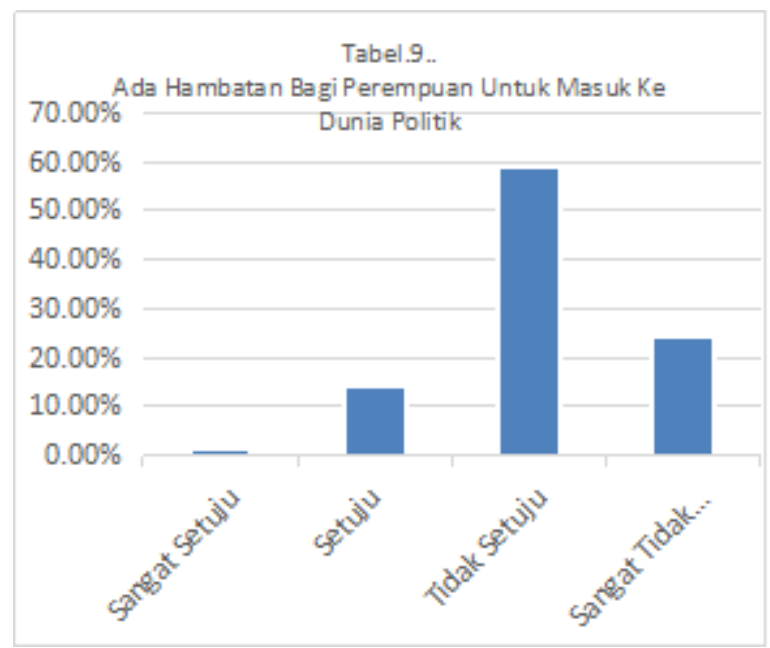

(59\%) menyatakan tidak setuju, (24,4\%) menyatakan sangat tidak setuju, $(14,4 \%)$ menyatakan setuju dan $(1,4 \%)$ menyatakan sangat setuju. Memang sebagian besar menyatakan tidak ada hambatan bagi perempuan untuk masuk dalam bidang politik. Namun Namun 14,4 \% responden dan $1,4 \%$ responden menyatakan setuju dan sangat setuju dengan pernyataan tersebut. Artinya masih ada hambatan bagi perempuan untuk bekerja di bidang politik karena anggapan masyarakat.

Aspek politik juga diukur dari persoalan kepemimpinan.Pertanyaan yang disampaikan apakah syarat jenis kelamin tertentu bagi jabatan tertentu. Hasil penelitian menunjukkan nahwa

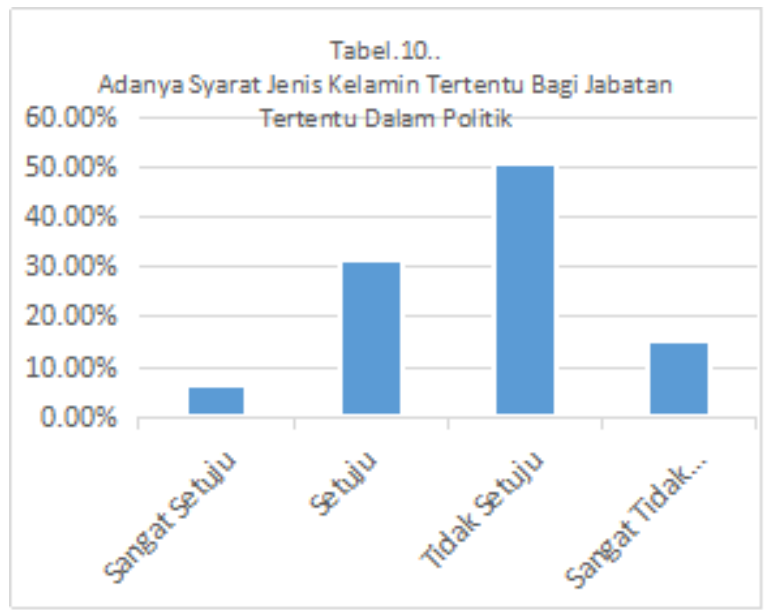

$(50,7 \%)$ menyatakan tidak setuju, (31,6\%) menyatakan setuju, $(15,3 \%)$ menyatakan sangat tidak setuju dan $(6,4 \%)$ menyatakan sangat setuju. Jika diperhatikan maka ada presentasi yang cukup dekat antara yang tidak setuju dengan yang setuju. Artinya dalam persoalan politik, masih banyak masyarakat yang menganggap bahwa perempuan tidak pantas berada dalam dunia politik.

Masalah kepemimpinan juga merupakan indikator untuk melihat bias gender dalam aspek politik. Kali ini dinyatakan bahwa lakilaki memiliki peluang lebih besar untuk menjadi pemimpin dibandingkan dengan perempuan. Aspek ini selalu muncul dalam pembahasan tentang kepemimpinan, karena dalam bias gender diakui adanya anggapan bahwa untuk menjadi pemimpin lebih pantas jika seorang laki-laki. Terhadap aspek ini, hasil penelitian menunjukkan,

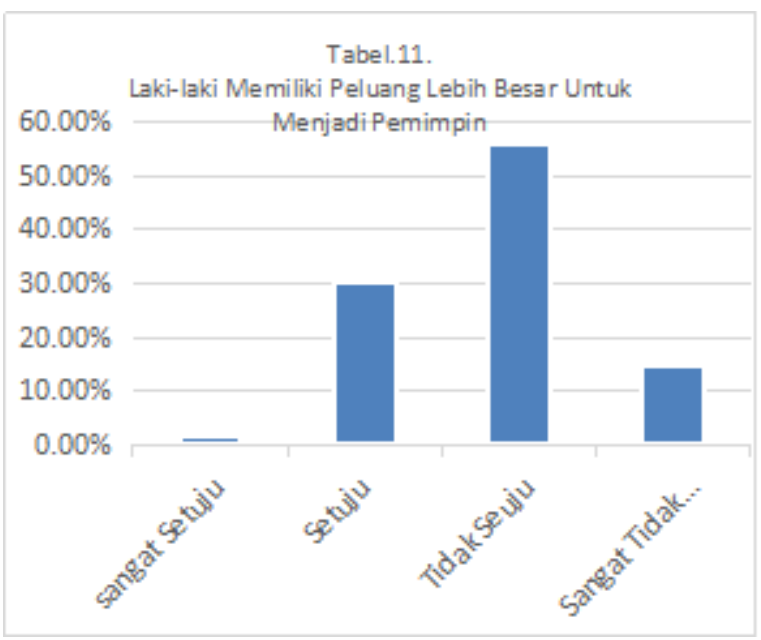

(56\%) menyatakan tidak setuju, $(30,1 \%)$ menyatakan setuju, $(14,8 \%)$ menyatakan sangat tidak setuju dan $(1,4 \%)$ menyatakan sangat setuju. Sama dengan pernyataan sebelumnya, sebagian besar menyatakan tidak setuju dengan pernyataan tersebut, namun dalam jumlah yang cukup besar $30,1 \%$ menyatakan setuju dengan pernyataan itu. Sehingga bias gender memang masih ada dalam aspek politik, terutama dalam hal peluang menjadi pemimpin.

Persolaan bias gender tidak hanya terjadi saat akan menjadi pemimpin, namun juga saat sudah menjadi pemimpin. Persepsi masyarakat yang menempatkan perempuan 
sebagai orang nomor dua dalam masyarakat, juga mempengaruhi bagaiamana menghargai pemimpin laki-laki dan pemimpin perempuan. Sehingga meskipun perempuan sudah bisa menjadi pemimpin, namun masih menghadapi persoalan penghargaan terhadap pemimpin laki dan pemimpin perempuan. Untuk melihat aspek ini, dinyatakan bahwa pemimpin laki-laki lebih dihargai dibanding dengan pemimpin perempuan. Dan jawaban terhadap pernyataan ini adalah,

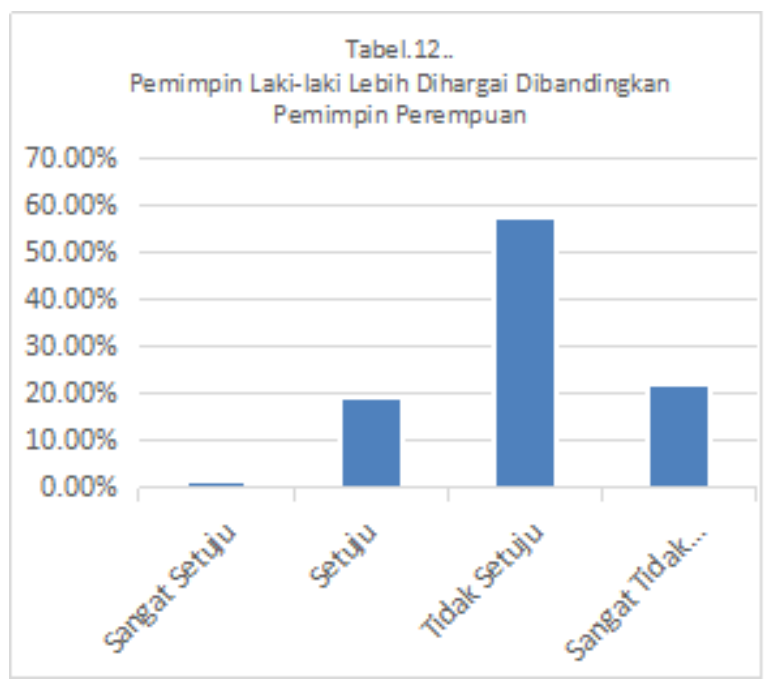

$(57,4 \%)$ menyatakan tidak setuju, (22\%) menyatakan sangat tidak setuju, $(19,1 \%)$ menyatakan setuju dan $(1,4 \%)$ menyatakan sangat setuju. Sehingga sebagian besar menyatakan bahwa pemimpin perempuan pun sama dihargainya dengan peimpin laki-laki. Walaupun $19,1 \%$ jawaban setuju menunjukkan bahwa masih ada anggapan yang bias dalam persoalan kepemimpinan.

\section{d. Beban Ganda}

Beban ganda dalah persoalan yang muncul dari konstruksi gender. Konstruksi gender selama ini menempatkan perempuan sebagai pihak yang bertanggung jawab terhadap pekerjaan domestik. Namun seiring perkembangan, ada kebutuhan bagi perempuan untuk ikut serta dalam mencari nafkah di ranah publik. Dalam kasus ini perempuan sudah memiliki keberdayaan dan posisi tawar sebagai pihak yang bekerja di sektor publik. Namun demikian tidak terjadi perubahan pada anggapan bahwa yang bertanggung jawab terhadap pekerjaan domestik adalah perempuan. Sehingga selain bekerja sebagai pencari nafkah keluarga, perempuan tetap bertanggung jawab utama dalam pekerjaan domestik. Hal ini justru menempatkan perempuan dalam masalah beban kerja ganda, yaitu sebagai pencarai nafkah dan sekaligus sebagai penanggungjawab pekerjaan rumah tangga.

Dinyatakan bahwa perempuanlah yang bertanggungjawab terhadap pekerjaan rumah tangga.Hasil dari penelitian dilapangan menunjukkan,

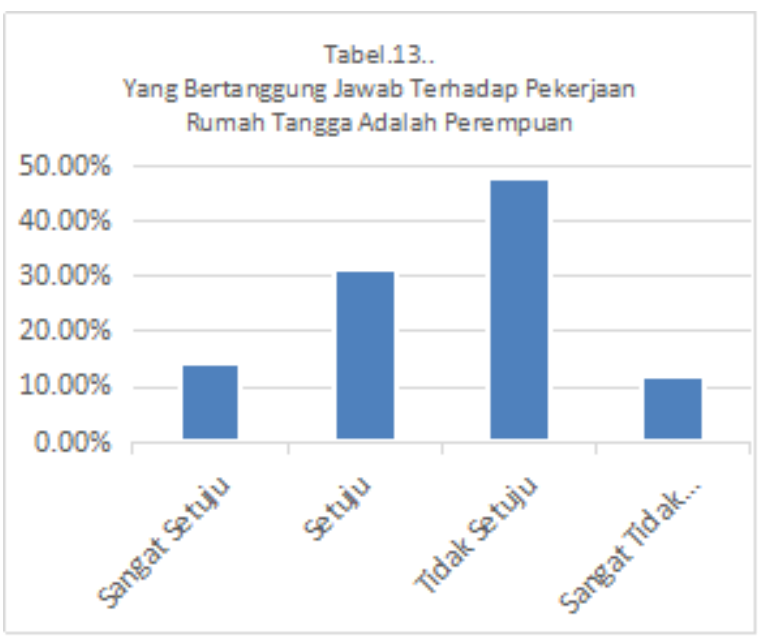

$(47,8 \%)$ menyatakan tidak setuju, $(31,5 \%)$ menyatakan setuju, $(14,4 \%)$ menyatakan sangat setuju dan (12\%) menyatakan sangat tidak setuju. Dengan demikian bisa dilihat bahwa sebagian besar jawaban terbagi dalam dua pendapat yaitu setuju dan tidak setuju

Pertanyaan selanjutnya adalah tentang siapa yang lebih banyak melakukan pekerjaan rumah, apakah laki-laki atau perempuan? Pertanyaan penelitiannya adalah sebagai berikut, perempuan melakukan pekerjaan rumah tangga lebih banyak dibandingakan dengan laki-laki. Hasil penelitian menunjukkan 


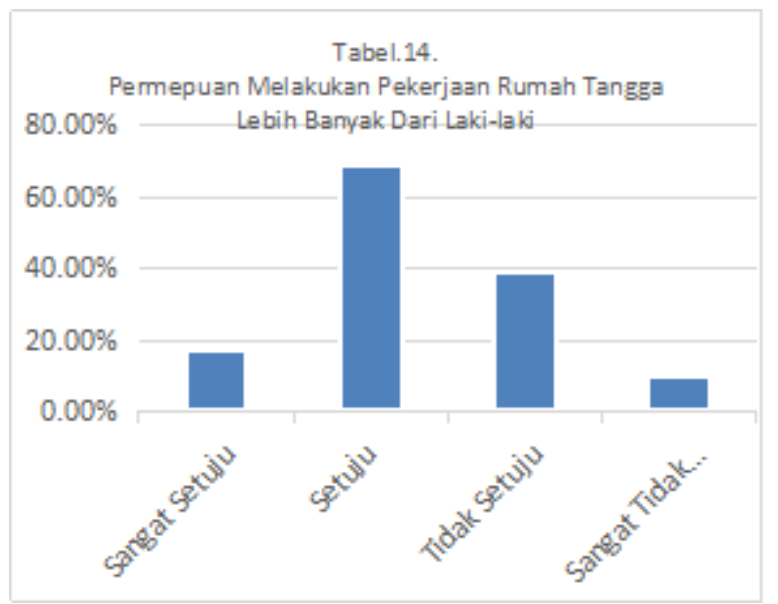

(69\%) menyatakan setuju, $(39,3 \%)$ menyatakan tidak setuju, (10\%) menyatakan sangat tidak setuju dan (17\%) sangat setuju. Disini kita bisa melihat bahwa perempuan masih dominan melakukan pekerjaan rumah tangga lebih banyak jika dibandingkan dengan laki-laki. Artinya masih ada anggapan di masyarakat bahwa pekerjaan domestik identik dengan perempuan.

Berkaitan dengan aspek beban ganda ini, ditegaskan lagi dengan pernyataan meskipun perempuan sudah bekerja tetapi melakukan pekerjaan rumah tangga lebih banyak dari lakilaki. Dan hasil penelitian menyampaikan gambaran sebagai berikut,

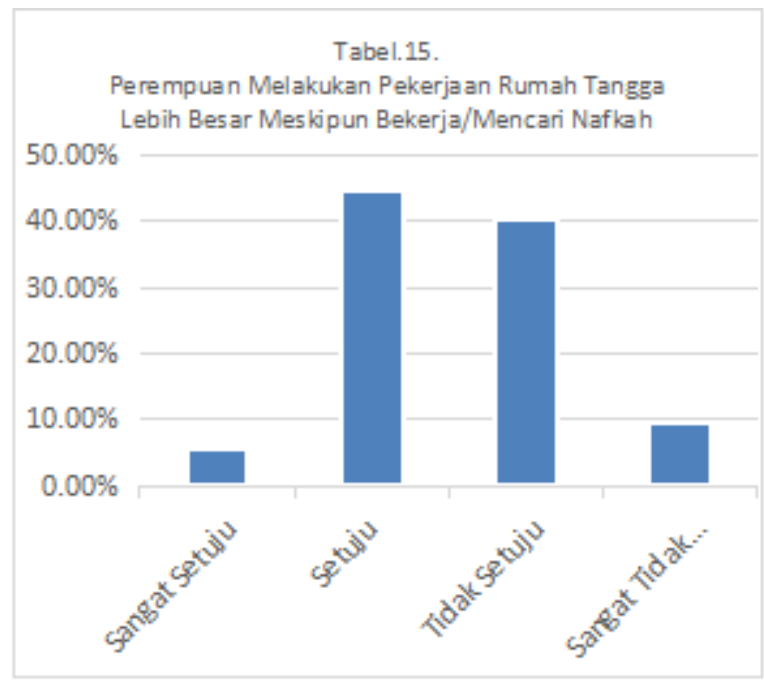

$(44,5 \%)$ menyatakan setuju, (40,1\%) menyatakan tidak setuju, $(9,6 \%)$ menyatakan sangat tidak setuju dan $(5,7 \%)$ menyatakan sangat setuju. Dengan demikian bisa ditakan, bahkan memang sebagian besar mengalami diskriminsi gender dalam bentuk beban ganda. Dan jika dibandingkan dengan pernyataan sebelumnya, beban ganda perempuan ini semakin terasa berat bagi perempuan yang bekerja mencari nafkah atau yang berkarya di ranah publik.

\section{KESIMPULAN}

Dari data diatas dapat dilihat bahwa masyarakat Yogyakarta benar memang megalami proses modernisasi. Secara umum bisa kita lihat bahwa memang terjadi perubahan terhadap konstruksi gender. Sepeti dibahas dalam awal tulisan ini, bahwa konstruksi gender telah menyebabkan ada ketidakadilan dalam memberikan pendidikan antara laki-laki dan perempuan. Dengan masyarakat yang lebih modern saat ini, sudah tidak ada lagi ketidakadilan dalam bidang pendidikan. Memang masih ada anggapan di masyarakat yang menyatakan ada ketidakadilan dalam pendidikan, namun angkanya sangat sedikit.

Sama halnya dengan aspek ekonomi dalam konstruksi gender. Antara laki-laki dan perempuan sudah tidak ada lagi ketidakadilana atau perlakuan yang berbeda dalam masyarakat. Hal ini menunjukkan konstruksi terhadap aspek ekonomi juga sudah berubah. Meskipun masih ada juga sedikit masyarakat yang merasakan adanya ketidakadilan tersebut

Dalam aspek politik juga sama dengan kedua aspek yang lain. Moderniasi ternyata membawa masyarakat berpikir lebih rasional dalam kehidupan politik. Tidak ada perbedaan perlakukan antara laki-laki dan perempuan. Walaupun masih juga ditemukan masyarkat yang berpendapat tidak adil.

Aspek ke empat beban ganda menunjukkan fenomena yang sedikit berbeda. Ternyata dalam aspek yang satu ini, masih banyak mesyarakat dengan konstruksi yang lama. Yaitu bahwa pekerjaan rumah tangga adalah pekerjaan perempuan. Sehingga perempuan melakukan lebih banyak dan dianggap lebih bertanggung jawab jika dibandingkan dengan laki-laki.

Dapat disimpulkan bahwa memang modernisasi telah membawa masyaarkat berpikir lebih resional dan lebih pragmatis. Dan cara 
berpikir yang lebih rasional dan pragmatis ini juga merubah konstruksi gender yang ada.

Namun sama dengan yang disampaikan oleh John Scott bahwa rentang tindakan yang tunduk kepada yang non-rasional semakin sedikit dan semakin mengecil dan hanya terbatas pada lingkup keluarga, kekerabatan dan tempattempat yang sifatnya pribadi. Dan ini terlihat dari gambaran diatas bahwa anggapan atau konstruksi yang tidak adil dalam gender yang lebih banyak terjadi adalah dalam aspek domestik, seperti beban ganda.

\section{DAFTAR PUSTAKA}

Browne, Jude. (2007). The Puture of Gender. Cambridge : University Press,.

Cleves, Julia. (2007). Gender dan Pengembangan. Yogyakarta : PustakaPelajar.

Fakih,Mansour. (2007). Anilisi Gender dan Ttransformasi Social., Yogyarkata : PustakaPelajar.

Giddens,Anhthony. (2014). KonsekuensiKonsekuensi Modernitas. Yogyakarta: Kreasi Wacana Ofset.

Jary, David and Julia. (1991). Dictionary of Sociology. Harper Collins Publisher,

Kerlinger, Fred, N. (1973). Foundation Of Behavioral Research, Second Edition, New
York University. New York : Holt Reinhart and Winston. Inc.

M King, Elizabeth. (2005). Pembangunan Perspektif Gender. Jakarta : Dian Rakyat.

Nazir, Moh. (1988). Metode Penelitian. Jakarta : Ghalia Indonesia.

Ollenberg, Jane and Moore, Helen. (1996). Sosiologi Wanita. Jakarta : Rinek A Cipta.

Permanadeli, Risa. (2015). Dadi Wong Wadon, Representasi Sosial Perempuan Jawa di Era Modern. Yogyakarta : Pustaka Ifada.

Salim, Agus. (2001). Teori dan Paradigma Penelitian Sosial, dari Denzin Guba dan Penerapannya. Yogyakarta; Tiara Wacana.

Suradiredja, Diah Y dan Jpang, Syafrizaldi. (2014). Perempuan di Singgasana Lelaki, Atlas Pemimpin Perempuan Indonesia. Jakarta : Gramedia,.

Scott, John. (2012). Teori Sosial, MasalahMasalah Pokok Dalam Sosiologi. Yogyakarta : Pustaka Pelajar.

Salhi, Smail Zahia. (2013). Gender and Violence in Islamic Societies, Patriarchy, Islamism and Politics in The Middle East and North Africa, I.B.Tauris\& Co Ltd. 